\title{
The Relationship between Bank Specific Characteristics and the Extent of Disclosure: Evidence from the Banking Sector in Bangladesh
}

\author{
Sumi Saha ${ }^{1}$, Taposh Kumar Neogy ${ }^{2 *}$
}

${ }^{1}$ Assistant Professor, Department of Accounting and Information Systems (AIS), University of Rajshahi, Rajshahi 6205, BANGLADESH

${ }^{2} \mathrm{PhD}$, Department of Accounting and Information Systems (AIS), University of Rajshahi, Rajshahi - 6205, BANGLADESH

${ }^{*}$ Corresponding Contact:

Email: neogyais@gmail.com

Manuscript Received: 13 June 2021

Accepted: 21 Aug 2021

\begin{abstract}
The fundamental motive of this study is to inspect the extent of disclosure of the banking companies in Bangladesh. To calculate the disclosure score of each sample bank, the un-weighted disclosure index has been used. To reveal the findings of this study, researchers have considered five conventional private commercial banks. A period of five years ranging from 2013 to 2017 has been selected for the study. Data have been collected from secondary sources and different statistical techniques like descriptive statistics as well as regression analysis with respective model have been employed. The study reveals that the average disclosures scores of the sample banks are in satisfactory level and the significant variation doesn't exist in the disclosure scores among the sample banks. Multiple regression analysis has been conducted to know whether the significant relationship is available between the extent of disclosure and the specific characteristics of banks and the evidence confirms that the significant relationship is existing between the extent of disclosure and earnings per share, return on assets as well as net profit but not between the disclosure scores and capital adequacy ratio, debt-equity ratio, current ratio, loan deposit ratio, market capitalization ratio as well as total assets.
\end{abstract}

Keywords: Disclosure Index, Voluntary Disclosure, Mandatory Disclosure, Disclosure Measurement, Private Commercial Banks

This article is is licensed under a Creative Commons Attribution-NonCommercial 4.0 International License. Attribution-NonCommercial (CC BY-NC) license lets others remix, tweak, and build upon work non-commercially, and although the new works must also acknowledge \& be non-commercial.

\section{INTRODUCTION}

The banking system is considered as the heart of an economy because of its contribution toward the mobilization of savings and thus to the utilization of this country's resources. The financial sector is largely dominated by the banking corporation in Bangladesh. That's why the macroeconomic development as well as the coherence of the motion of industries are depending on the progression of banking system (Yesmine and Bhuiyah, 2015; Siddique et al., 2014). From a commercial bank, information required by regulatory bodies and Acts are to be 
published in the annual reports for the related parties. So, because of making proper decisions, the qualitative and quantitative information needs to be analyzed by the recipients (Hawashe, 2015). The concept of full disclosure states that all available and required information be communicated or made available to ensure satisfaction of the different stakeholders. Disclosure is related to providing information required for making business and economic decisions by the interested parties generally who have the right to observe it. Accounting has been considered as an information system of which the financial statements are the end products. The summarized and classified statements of the financial transactions are considered as the financial statements. Some basic means of financial disclosure are the balance sheet, profit and loss account, cash flow statement etc. (Maleque et al., 2010). The financial statements should disclose the relevant information clearly and fully. This situation should prevail for achieving the optimum operations of the congenial capital markets. The implications of this attribute predict the manners of future dividend and the variability of returns. The ultimate goal of the disclosure is to communicate with the necessary information timely by which the reliability and useful decisions can be built in an intelligible manner (Maleque et al., 2010). The total banking sector ensures the sustainable economic development of any country. Every state has its own regulatory forms of disclosing information of the banking corporation. While disclosing accounting information, the banking sector in Bangladesh follows the Companies Act 1994, the Banking Companies Act, 1991, Securities and Exchange Rules 1987, Securities and Exchange Ordinance, 1869, International Accounting Standards/ International Financial Accounting Standards and the guidelines of Bangladesh Bank from time to time. According to the different stakeholder's point of view, corporate disclosure is an essential means to communicate the corporate information for making effective decisions (Neogy \& Ahmed, 2014). In these circumstances, this study is conducted to examine the level of disclosure of information of the sample banks and to determine its existing relationship with the specifics characteristics of the commercial banks.

\section{Objectives of the Study}

To examine the extent of disclosure of the annual reports and determine its relationship with the specific characteristics of banks are the basic objective of this study. Therefore, the researchers have set the following specific objectives:

- To know the extent of disclosing information by the banking companies in Bangladesh.

- To examine the association between the extent of disclosure and specific characteristics of banks.

\section{Literature Review and Hypotheses Development}

Hasan and Hosain (2015) stated that the average 71\% of the companies analyzed disclose above-average additional information. The level of voluntary disclosure in the annual reports of Bangladeshi companies is significantly and positively affected by firm size consists of total asset and status of the company. Profitability and company age were not found statistically significant in case of voluntary disclosure level. In addition company age and the status of the company have appeared to be significant factors for mandatory disclosure but company sizes surrogated by total assets as well as sales and company profitability have no effect on mandatory disclosure. Hossain (2008) reported that the average disclosure score of mandatory items are 88 and the average score of voluntary disclosure is 25 . He also reported that size, profitability, board composition and market discipline variables are significant but the remaining variables like age, the complexity of 
business and asset-in-place is insignificant in explaining the level of disclosure. Galani (2011) revealed that the firm size was positively associated with the level of disclosure but the rest variables such as age, profitability, liquidity, and board composition was found to be insignificant in explaining the variation of mandatory disclosures. Hawashe (2015) explained that the bank's size and listing status are significantly associated with the level of voluntary information disclosures. The author also explained that the extent of voluntary disclosure in annual reports is not significantly influenced by the other bank attributes. Barako (2007) concluded in his study that the voluntary disclosure scores show that the level of disclosure by Kenyan companies for all categories of information is low but the disclosures of all types of information are influenced by corporate governance attributes, ownership structure, and corporate characteristics. In the light of the aforesaid discussion this study has formulated and tested the following null hypotheses:

$\mathrm{H}_{\circ 1}$ : There is no significant variation in disclosure information in annual reports among the sample banks under the study period.

$\mathrm{H}_{\mathrm{o} 2}$ : There is no significant relationship between the bank-specific characteristics and the extent of disclosure information of the banking companies in Bangladesh.

\section{Methodology of the Study}

In Bangladesh, the banking sector is comprises of several types such as State-Owned Commercial Banks (6), Specialized Banks (3), Private Commercial Banks (41), and Foreign Commercial Banks (9) (www.bb.org.bd). In this research study, five private commercial banks viz Pubali Bank Limited (here in after SB_1), Uttara Bank Limited (here in after SB_2), National Bank Limited (here in after SB_3), AB Bank Limited (here in after SB_4) and IFIC Bank Limited (here in after SB_5) has been selected as the sample which are listed in the Dhaka Stock Exchange. State-owned commercial Banks except for Rupali Bank Limited, Specialized Banks and Foreign Commercial Banks in Bangladesh are not enlisted under Dhaka Stock Exchange (www.dse.com.bd). Consequently state-owned commercial Banks, Specialized Banks, and Foreign Commercial Banks have not been considered in our study. The purposive sampling technique has been used where the units that are chosen based on the judgment of the researchers. This study has considered a period of five years ranging from 2013 to 2017 due to the fact that this period does not suffer from abnormality. The researchers have used the secondary data which is gathered from the annual reports of the above sample banks.

Statistical Techniques: To analyze the collected data, this study conducted the expository statistics such as mean, standard deviation, coefficient of variation, maximum value and minimum value. The regression analysis and ANOVA technique are also used here.

Dependent and Independent Variables: In this study, an unweighted disclosure score has been taken as the dependent variable. On the other hand, the total assets, earnings per share, net profit, debt-equity ratio, loan deposit ratio, and return on assets, current ratio, capital adequacy ratio and market capitalization ratios have been used as independent variables. Here, the independent variables have been taken from the earlier studies conducted by the different researchers in different countries.

Construction of Disclosure Index: The disclosure index has been made to inform about the level of disclosure score of the listed banking companies. Two kinds of disclosure indices have been stated, weighted index and un-weighted index by the researchers. Here, an un-weighted index containing 155 items of information regarding the voluntary and mandatory items has been constructed. A score zero has been given for each item if it is 
not disclosed. On the other hand, a score one has been awarded for the disclosed item containing in the annual reports. To get the disclosure percentage, total raw score has been divided by the total number of items and multiplied by 100 .

$$
T D S=\sum_{i=1}^{n} d i
$$

Where,

TDS= Total Disclosure Scores

$\mathrm{d}=1$ if the item di is disclosed

$\mathrm{d}=0$ if the item di is not disclosed and

$\mathrm{n}=$ number of items.

The following Table clearly sates the included items.

Table 1: Table showing the different parts of un-weighted disclosure index

\begin{tabular}{|l|c|c|}
\hline \multicolumn{1}{|c|}{ Different Parts } & Individual Items & \% of Total Items \\
\hline General Corporate Items & 10 & 6.45 \\
\hline Accounting Policy Items & 24 & 15.48 \\
\hline Balance Sheet Assets Items & 18 & 11.61 \\
\hline Balance Sheet Liabilities Items & 19 & 12.26 \\
\hline Income Statement Debit Items & 15 & 9.68 \\
\hline Income Statement Credit Items & 11 & 7.10 \\
\hline Financial Perspective Items & 27 & 17.42 \\
\hline Information Relating to Project & 13 & 8.39 \\
\hline Management Discussion and Analysis Items & 18 & 11.61 \\
\hline Total & 155 & 100 \\
\hline
\end{tabular}

Source: Researchers Own Calculation from Annual Reports

\section{Results AND Discussion}

\section{Sample Wise Descriptive Statistics of Disclosure Scores}

On the basis of aforesaid information, it exposes that the sample bank_3 reports the highest average disclosure percentage and sample bank _ 1 shows the lowest average disclosure percentage. However, sample bank _ 5 shows the lowest standard deviation, and sample bank_1 shows the highest standard deviation. The observed variance regarding the sample bank _ 1 is getting the highest level and in the case of sample bank _5, it is lowest level respectively. The Table also indicates that sample bank_2 and sample bank_1 results the maximum and minimum level of disclosure percentage in this study.

Table 2: Table shows the expository results of the disclosure scores:

\begin{tabular}{|c|c|c|c|c|c|c|c|}
\hline & Minimum & Maximum & Mean & SD & Variance & Skewness & Kurtosis \\
\cline { 2 - 8 } & Statistic & Statistic & Statistic & Statistic & Statistic & Statistic & Statistic \\
\hline SB_1 & 74.81 & 80.71 & 77.8720 & 2.64403 & 6.991 & .220 & -2.568 \\
\hline SB_2 & 78.10 & 83.18 & 79.8360 & 2.16238 & 4.676 & 1.169 & .111 \\
\hline SB_3 & 79.03 & 83.14 & 80.5000 & 1.78182 & 3.175 & .984 & -.815 \\
\hline SB_4 & 75.77 & 81.87 & 78.5380 & 2.50374 & 6.269 & .469 & -1.686 \\
\hline SB_5 & 77.71 & 82.00 & 80.4900 & 1.65277 & 2.732 & -1.601 & 2.967 \\
\hline
\end{tabular}

Source: Researchers Own Calculation from Annual Reports 
So, based on the above assessment, the increasing and decreasing trend has been observed satisfactorily under this study period as per disclosing of information and the percentages of disclosure.

\section{Variation of Disclosure Scores among the Sample Banks}

To find out the existence of significant variation among the sample banks, the researchers used ANOVA test by means of SPSS with the null hypothesis $\mathrm{H}_{\circ 1}$ : There is no significant variation in disclosure scores among the sample banks over the study period and the following is the result of ANOVA testing result.

Table 3: Table shows the results of ANOVA test:

\begin{tabular}{|c|c|c|c|c|c|}
\hline & Sum of Squares & $\mathrm{df}$ & Mean Square & F Ratio & Sig. Level \\
\hline Between Groups & 28.274 & 4 & 7.069 & 1.482 & 0.245 \\
\hline Within Groups & 95.368 & 20 & 4.768 & & \\
\hline Total & 123.643 & 24 & & & \\
\hline
\end{tabular}

Source: Researchers Own Calculation from Annual Reports

The results of ANOVA test displays that the F ratio is 1.482 and its significant level is 0.245 which is higher than 0.05 levels and it means that the null hypothesis is accepted. This indicates that there is no significant variation in disclosure scores among the sample banks during the study period.

Disclosure Scores and Its Relationship with the Specific Characteristics of Banks: Based on previous studies of the banks some specific characteristics have been taken into consideration in this study such as earnings per share, return on assets, total assets, net profit, loan deposit ratio, current ratio, debt equity ratio, capital adequacy ratio and market capitalization (Hussain et al., 2021; Sharma et al., 2021; Ahmed et al., 2021; Zhu et al., 2021; Ahmed et al., 2016). To be informed about the existence of significant relationship of the specific characteristics of banks with the extent of disclosure, the researchers have conducted the regression analysis with respective regression model and the null hypothesis is $\mathrm{H}_{\mathrm{o} 2}$ : There is no significant relationship between the specific characteristics of banks and the extent of disclosure contained in annual reports of the sample banks. To report about the relationship between one independent variable and a dependent variable, the study has employed simple regression with the formation of the respective null hypothesis and its results are placed in the following section.

\section{Disclosure Scores vs. Total Assets}

$\mathrm{H}_{\mathrm{o} 2.1:}$ There is no significant relationship between the size of the total assets and the extent of disclosure of the sample banks.

Table 4: Table shows the outcomes of regression analysis between the disclosure scores and the total asset:

\begin{tabular}{|c|c|c|c|c|}
\hline Samples Banks & $\mathbf{R}^{\mathbf{2}}$ & F ratios & SL & Decisions \\
\hline Bank_1 & 0.888 & 23.693 & 0.017 & Significant \\
\hline Bank_2 & 0.809 & 12.688 & 0.038 & Significant \\
\hline Bank_3 & 0.547 & 3.619 & 0.153 & Insignificant \\
\hline Bank_4 & 0.420 & 2.171 & 0.237 & Insignificant \\
\hline Bank_5 & 0.661 & 5.837 & 0.095 & Insignificant \\
\hline
\end{tabular}

Source: Researchers Own Calculation from Annual Reports 
Considering the outcomes of regression analysis, the result shows that the null hypothesis is rejected in case of sample bank _ 1 and 2. On the other hand, the null hypothesis is accepted in case of sample bank_3,4, and 5. This result confirms that a significant and insignificant relationship exist between the size of the total assets and the extent of disclosure of the sample banks.

\section{Disclosure Scores vs. Net Profit}

$\mathrm{H}_{\text {o2.2: }}$ There is no significant relationship between the net profit and the extent of disclosure of the sample banks.

Table 5: The Table shows the outcome of regression analysis between disclosure scores and net profit:

\begin{tabular}{|c|c|c|c|c|}
\hline Samples Banks & $\mathbf{R}^{\mathbf{2}}$ & F ratios & SL & Decisions \\
\hline Bank_1 & 0.426 & 2.228 & 0.232 & Insignificant \\
\hline Bank_2 & 0.465 & 2.607 & 0.205 & Insignificant \\
\hline Bank_3 & 0.642 & 5.375 & 0.103 & Insignificant \\
\hline Bank_4 & 0.461 & 2.567 & 0.207 & Insignificant \\
\hline Bank_5 & 0.141 & 0.492 & 0.533 & Insignificant \\
\hline
\end{tabular}

Source: Researchers Own Calculation from Annual Reports

As per the aforesaid results of the regression analysis the null hypothesis is accepted in all cases. This figure states that the significant relationship doesn't exist between the net profit and the extent of disclosure of the sample banks.

\section{Disclosure Scores vs. Return on Assets}

$H_{\text {o2.3: }}$ There is no significant relationship between the return on assets and the extent of disclosure of the sample banks

Table 6: The table shows the results of regression analysis between disclosure scores and return on assets:

\begin{tabular}{|c|c|c|c|c|}
\hline Samples Banks & $\mathbf{R}^{\mathbf{2}}$ & F ratios & SL & Decisions \\
\hline Bank_1 & 0.823 & 13.983 & 0.033 & Significant \\
\hline Bank_2 & 0.958 & 68.111 & 0.004 & Significant \\
\hline Bank_3 & 0.389 & 1.912 & 0.261 & Insignificant \\
\hline Bank_4 & 0.584 & 4.205 & 0.133 & Insignificant \\
\hline Bank_5 & 0.138 & 0.482 & 0.538 & Insignificant \\
\hline
\end{tabular}

Source: Researchers Own Calculation from Annual Reports

The results of regression analysis portray that in case of sample bank_1 and sample bank_2 the null hypothesis is rejected. On the other hand, it is accepted in case of sample bank_3, 4, 5. This pictorial view confirms that a significant relationship exists between the return on assets and the extent of disclosure in case of the sample bank _ 1 and 2 but the significant relationship doesn't exist between the return on assets and the extent of disclosure regarding the sample bank_3, 4, and 5 over the study period.

\section{Disclosure Scores vs. Earnings per Share}

$\mathrm{H}_{\mathrm{o} 2.4}$ : There is no significant relationship between the earnings per share and the extent of disclosure of the sample banks. 
Table 7: The table shows the outcomes of regression analysis between disclosure scores and earnings per share:

\begin{tabular}{|c|c|c|c|c|}
\hline Samples Banks & $\mathbf{R}^{\mathbf{2}}$ & F ratios & SL & Decisions \\
\hline Bank_1 & 0.656 & 5.712 & 0.097 & Insignificant \\
\hline Bank_2 & 0.464 & 2.597 & 0.205 & Insignificant \\
\hline Bank_3 & 0.460 & 2.558 & 0.208 & Insignificant \\
\hline Bank_4 & 0.545 & 3.599 & 0.154 & Insignificant \\
\hline Bank_5 & 0.307 & 1.328 & 0.333 & Insignificant \\
\hline
\end{tabular}

Source: Researchers Own Calculation from Annual Reports

The results of regression analysis accept the null hypothesis in all cases. It means, the significant relationship doesn't exist between the earnings per share and the extent of disclosure of the sample banks over the study period.

\section{Disclosure Scores vs. Current Ratio}

Ho2.5: There is no significant relationship between the current ratio and the extent of disclosure of the sample banks.

Table 8: The Table showing the outcomes of regression analysis between disclosure scores and current ratio:

\begin{tabular}{|c|c|c|c|c|}
\hline Samples Banks & $\mathbf{R}^{\mathbf{2}}$ & F ratios & SL & Decisions \\
\hline Bank_1 & 0.052 & 0.165 & 0.712 & Insignificant \\
\hline Bank_2 & 0.609 & 4.670 & 0.119 & Insignificant \\
\hline Bank_3 & 0.681 & 6.400 & 0.085 & Insignificant \\
\hline Bank_4 & 0.064 & 0.205 & 0.681 & Insignificant \\
\hline Bank_5 & 0.093 & 0.309 & 0.617 & Insignificant \\
\hline
\end{tabular}

Source: Researchers Own Calculation from Annual Reports

The results of regression analysis accept the null hypothesis in the case of all sample banks. It means the significant relationship doesn't exist between the current ratio and the extent of disclosure of the sample banks.

\section{Disclosure Scores vs. Debt Equity Ratio}

$\mathrm{H}_{\text {o2.6: }}$ There is no significant relationship between the debt-equity ratio and the extent of disclosure of the sample banks.

Table 9: The Table shows the outcomes of regression analysis between the disclosure scores and the debt-equity ratio:

\begin{tabular}{|c|c|c|c|c|}
\hline Samples Banks & $\mathbf{R}^{\mathbf{2}}$ & F ratios & SL & Decisions \\
\hline Bank_1 & 0.791 & 11.369 & 0.043 & Significant \\
\hline Bank_2 & 0.696 & 6.875 & 0.079 & Insignificant \\
\hline Bank_3 & 0.342 & 1.562 & 0.300 & Insignificant \\
\hline Bank_4 & 0.030 & 0.094 & 0.779 & Insignificant \\
\hline Bank_5 & 0.097 & 0.323 & 0.609 & Insignificant \\
\hline
\end{tabular}

Source: Researchers Own Calculation from Annual Reports

The results of regression analysis rejected the null hypothesis in case of sample bank _1 and the significant relationship exists between the debt-equity ratio and the extent of disclosure in this case but the null hypothesis is accepted in the case of the remaining four 
sample banks. It means the significant relationship doesn't exist between the debt-equity ratio and the extent of disclosure in case of sample bank_2, 3, 4, and 5 over the study period.

\section{Disclosure Scores vs. Loan Deposit Ratio}

$\mathrm{H}_{\mathrm{o} 2.7}$ : There is no significant relationship between the loan deposit ratio and the extent of disclosure of the sample banks.

Table 10: The Table shows the outcomes of regression analysis between disclosure scores and loan deposit ratio:

\begin{tabular}{|c|c|c|c|c|}
\hline Samples Banks & $\mathbf{R}^{\mathbf{2}}$ & F ratios & SL & Decisions \\
\hline Bank_1 & 0.701 & 7.021 & 0.077 & Insignificant \\
\hline Bank_2 & 0.472 & 2.682 & 0.200 & Insignificant \\
\hline Bank_3 & 0.581 & 4.165 & 0.134 & Insignificant \\
\hline Bank_4 & 0.143 & 0.501 & 0.530 & Insignificant \\
\hline Bank_5 & 0.614 & 4.775 & 0.117 & Insignificant \\
\hline
\end{tabular}

Source: Researchers Own Calculation from Annual Reports

The outcomes of regression analysis accepted the null hypothesis is in case of all the sample banks. This figure states that the significant relationship doesn't exist between loan deposit ratio and the extent of disclosure of the sample banks.

\section{Disclosure Scores vs. Capital Adequacy Ratio}

$\mathrm{H}_{\mathrm{o} 2.8}$ : There is no significant relationship between the capital adequacy ratio and the extent of disclosure of the sample banks.

Table 11: The Table shows the outcomes of regression analysis between the disclosure scores and the capital adequacy ratio:

\begin{tabular}{|c|c|c|c|c|}
\hline Samples Banks & $\mathbf{R}^{\mathbf{2}}$ & F ratios & SL & Decisions \\
\hline Bank_1 & 0.079 & 0.258 & 0.647 & Insignificant \\
\hline Bank_2 & 0.445 & 2.404 & 0.219 & Insignificant \\
\hline Bank_3 & 0.421 & 2.179 & 0.236 & Insignificant \\
\hline Bank_4 & 0.164 & 0.590 & 0.498 & Insignificant \\
\hline Bank_5 & 0.294 & 1.248 & 0.345 & Insignificant \\
\hline
\end{tabular}

Source: Researchers Own Calculation from Annual Reports

The results of regression analysis accepted the null hypothesis in all cases. It means the significant relationship doesn't exist between the capital adequacy ratio and the extent of disclosure of the sample banks over the study period.

\section{Disclosure Scores vs. Market Capitalization}

Ho2.9: There is no significant relationship between the market capitalization and the extent of disclosure of the sample banks.

After observing the regression analysis, it is evident that the null hypothesis is rejected in the case of sample bank_3 and accepted in case of sample bank_1, 2, 4 and 5. This view point indicates that a significant and insignificant relationship exists between the market capitalization ratio and the extent of disclosure of the sample banks. 
Table 12: The Table shows the outcomes of regression analysis between the disclosure scores and the market capitalization ratio

\begin{tabular}{|c|c|c|c|c|}
\hline Samples Banks & $\mathbf{R}^{\mathbf{2}}$ & F ratios & SL & Decisions \\
\hline Bank_1 & 0.020 & 0.061 & 0.821 & Insignificant \\
\hline Bank_2 & 0.595 & 4.407 & 0.127 & Insignificant \\
\hline Bank_3 & 0.850 & 16.998 & 0.026 & Significant \\
\hline Bank_4 & 0.106 & 0.355 & 0.593 & Insignificant \\
\hline Bank_5 & 0.140 & 0.488 & 0.535 & Insignificant \\
\hline
\end{tabular}

Source: Researchers Own Calculation from Annual Reports

\section{Specification of Regression Model}

The given study has designed the multiple regression analysis with OLS model and null hypothesis because of reporting about the relationship between the entire dependent and the independent variables. The designed null hypothesis is Ho2.10: There is no significant relationship between the entire independent variables and the extent of disclosure of the sample banks. The following section has been tabulated the findings of the regression model in this study.

\section{Regression Model}

$$
\mathrm{TDS}=\boldsymbol{\alpha}+\boldsymbol{\beta}_{1} \mathrm{TA}+\boldsymbol{\beta}_{2} \mathrm{NP}+\boldsymbol{\beta}_{3} \mathrm{ROA}+\boldsymbol{\beta}_{4} \mathrm{EPS}+\boldsymbol{\beta}_{5} \mathrm{CR}+\boldsymbol{\beta}_{6} \mathrm{DER}+\boldsymbol{\beta}_{7} \mathrm{LDR}+\boldsymbol{\beta}_{8} \mathrm{CAR}+\boldsymbol{\beta}_{9} \mathrm{MC}+\varepsilon(t)
$$

Where, TDS $=$ Total Disclosure Scores, TA = Total Assets, NP = Net Profit, ROA = Return on Assets, EPS = Earnings per Share, $\mathrm{CR}=$ Current Ratio, DER = Debt Equity Ratio, LDR = Loan Deposit Ratio, CAR = Capital Adequacy ratio, MC = Market Capitalization, $\alpha=$ the constraint term of the model, $\beta=$ the coefficient of the model and $\varepsilon=$ the error term.

\section{Explanation of Multicollinearity Statistics}

Table 13: The Table shows the results of collinerity statistics

\begin{tabular}{|l|c|c|}
\hline \multirow{2}{*}{\multicolumn{1}{|c|}{ Variables }} & \multicolumn{2}{c|}{ Collinerity Statistics } \\
\cline { 2 - 3 } & Tolerance & VIF \\
\hline Capital Adequacy Ratio & 0.44475 & 2.24843 \\
\hline Current Ratio & 0.20820 & 4.80297 \\
\hline Debt Equity Ratio & 0.44640 & 2.24014 \\
\hline Earnings Per Share & 0.19957 & 5.01072 \\
\hline Loan Deposit Ratio & 0.15903 & 6.28826 \\
\hline Market Capitalization & 0.33431 & 2.99121 \\
\hline Net Profit & 0.22738 & 4.39784 \\
\hline Return on Assets & 0.10787 & 9.27056 \\
\hline Total Assets & 0.17169 & 5.82461 \\
\hline
\end{tabular}

Source: Researchers Own Calculation from Annual Reports

The above evidence reports the results of collinearity statistics regarding the different variables and the VIF (Variance Inflation Factor) has been used for displaying the multicollinearity in the multiple regression models. A statement has been cited from Arif \& Tuhin in 2013 as well as Rahman \& Uddin in 2016, if the VIF (Variance Inflation Factor) becomes more than 10, it is taken as a term of harmful multicollinearity. But the values of VIF (Variance Inflation Factor) of the total independent variables become less than 10, so, it has not been taken as a problematic issue. 


\section{Explanation of the Results of Model Summary}

Table 14: The Table shows the results of model summary

\begin{tabular}{|l|c|c|c|c|c|c|c|c|c|}
\hline Model & & & & Std. Error & \multicolumn{4}{|c|}{ Change Statistics } \\
\cline { 4 - 9 } & $\mathrm{R}$ & $\begin{array}{c}\mathrm{R} \\
\text { Square }\end{array}$ & $\begin{array}{c}\text { Adjusted } \\
\text { R Square }\end{array}$ & $\begin{array}{c}\text { of the } \\
\text { Estimate }\end{array}$ & $\begin{array}{c}\text { R Square } \\
\text { Change }\end{array}$ & $\begin{array}{c}\mathrm{F} \\
\text { Change }\end{array}$ & $\mathrm{df1}$ & $\mathrm{df2}$ & $\begin{array}{c}\text { Sig. F } \\
\text { Change }\end{array}$ \\
\hline One & 0.7829 & 0.6129 & 0.3806 & 1.7864 & 0.6129 & 2.6384 & 9 & 15 & 0.0467 \\
\hline Predictors: (Constant), TA, EPS, MCR, CAR, DER, NP, CR, LDR, ROA \\
\hline
\end{tabular}

Source: Researchers Own Calculation from Annual Reports

Referring to the results of the model the summary is evident that the value of $\mathrm{R}$ is 0.7829 that presents a simple correlation degree, R-square value is 0.6129 that indicates that $61.29 \%$ of the variability in the dependent variable (extent of disclosure) is explained by the independent variables, $\mathrm{F}$ statistics is 2.638 and its level (P-value) of significant is 0.0467 which is lower than 0.05 or $5 \%$ that rejected the null hypothesis and it confirms the existence of significant relationship between the extent of disclosure and the specific characteristics of banks like total assets, earnings per share, market capitalization, capital adequacy ratio, debtequity ratio, net profit, current ratio, loan deposit ratio and return on assets.

\section{Explanation of the Results of Coefficients}

Table 15: The Table shows the results of coefficients among the variables

\begin{tabular}{|c|c|c|c|c|c|}
\hline & \multicolumn{2}{|c|}{$\begin{array}{c}\text { Unstandardized } \\
\text { Coefficients }\end{array}$} & $\begin{array}{c}\text { Standardized } \\
\text { Coefficients }\end{array}$ & \multirow{2}{*}{ Sig. } & \\
\cline { 2 - 4 } & B & Std. Error & Beta & & \\
\hline (Constant) & 60.30911 & 10.10959 & & 5.96554 & 0.00003 \\
\hline CAR & 0.69143 & 0.53267 & 0.31270 & 1.29806 & 0.21387 \\
\hline CR & 2.73838 & 1.49169 & 0.64633 & 1.83575 & 0.08630 \\
\hline DER & 0.04862 & 0.12083 & 0.09676 & 0.40240 & 0.69306 \\
\hline EPS & 2.16382 & 0.80745 & 0.96370 & 2.67982 & 0.01714 \\
\hline LDR & 0.08161 & 0.09520 & 0.34535 & 0.85725 & 0.40479 \\
\hline MC & 0.00004 & 0.00010 & 0.12026 & 0.43281 & 0.67131 \\
\hline NP & 0.00196 & 0.00062 & 1.07110 & 3.17923 & 0.00622 \\
\hline ROA & -9.19086 & 2.73997 & -1.64079 & -3.35437 & 0.00435 \\
\hline TA & -0.00001 & 0.00001 & -0.50720 & -1.30815 & 0.21051 \\
\hline \multicolumn{7}{|l|}{ Dependent Variable: TDS }
\end{tabular}

Source: Researchers Own Calculation from Annual Reports

This assessment indicates that return on assets, the earnings per share and net profit expose the significant relationship with the extent of disclosure for having low value at $5 \%$ level of significance. On the other hand, the remaining variables like current ratio, capital adequacy ratio, loan deposit ratio, debt-equity ratio, market capitalization and total assets reveal the insignificant relationship with the extent of disclosure as per the higher significant levels at $5 \%$ level of significance.

\section{Explanation of Correlation Matrix}

To identify the correlation between the independent variables (such as Capital Adequacy Ratio, Current Ratio, Debt-Equity Ratio, Earnings Per Share, Loan Deposit Ratio, Market Capitalization, Net Profit, Return On Assets and Total Assets) and the dependent variable, 
the given study has employed the correlation matrix and the results in this regard are stated below:

Table 16: Table showing the results of correlation among the variables:

\begin{tabular}{|c|c|c|c|c|c|c|c|c|c|c|}
\hline & TDS & CAR & CR & DER & EPS & LDR & $\mathrm{MC}$ & NP & ROA & TA \\
\hline TDS & 1.000 & & & & & & & & & \\
\hline CAR & 0.128 & 1000 & & & & & & & & \\
\hline CR & $\begin{array}{l}0.257 \\
0.214\end{array}$ & $\begin{array}{c}-0.513^{* *} \\
0.009\end{array}$ & 1.000 & & & & & & & \\
\hline DER & $\begin{array}{l}0.217 \\
0.297\end{array}$ & $\begin{array}{l}0.192 \\
0.358\end{array}$ & $\begin{array}{l}0.086 \\
0.682\end{array}$ & 1.000 & & & & & & \\
\hline EPS & $\begin{array}{c}-0.024 \\
0.910\end{array}$ & $\begin{array}{l}0.340 \\
0.097\end{array}$ & $\begin{array}{c}-0.295 \\
0.152\end{array}$ & $\begin{array}{c}0.474^{*} \\
0.017\end{array}$ & 1.000 & & & & & \\
\hline LDR & $\begin{array}{l}0.156 \\
0.457\end{array}$ & $\begin{array}{c}-0.386 \\
0.057\end{array}$ & $\begin{array}{l}0.281 \\
0.174\end{array}$ & $\begin{array}{c}-0.476^{*} \\
0.016\end{array}$ & $\begin{array}{c}-0.760^{* * *} \\
0.000\end{array}$ & 1.000 & & & & \\
\hline MC & $\begin{array}{l}0.007 \\
0.974\end{array}$ & $\begin{array}{l}0.111 \\
0.597\end{array}$ & $\begin{array}{c}-0.361 \\
0.076\end{array}$ & $\begin{array}{l}0.004 \\
0.985\end{array}$ & $\begin{array}{l}-0.192 \\
0.357\end{array}$ & $\begin{array}{c}0.420^{*} \\
0.037\end{array}$ & 1.000 & & & \\
\hline NP & $\begin{array}{l}0.293 \\
0.156\end{array}$ & $\begin{array}{l}0.347 \\
0.089\end{array}$ & $\begin{array}{c}-0.114 \\
0.589\end{array}$ & $\begin{array}{l}0.087 \\
0.679\end{array}$ & $\begin{array}{c}-0.023 \\
0.913\end{array}$ & $\begin{array}{l}0.207 \\
0.322\end{array}$ & $\begin{array}{c}0.470^{*} \\
0.018\end{array}$ & 1.000 & & \\
\hline ROA & $\begin{array}{l}0.019 \\
0.927\end{array}$ & $\begin{array}{l}0.368 \\
0.070\end{array}$ & $\begin{array}{l}0.032 \\
0.878\end{array}$ & $\begin{array}{l}0.297 \\
0.149\end{array}$ & $\begin{array}{c}0.445^{*} \\
0.026\end{array}$ & $\begin{array}{c}-0.242 \\
0.244\end{array}$ & $\begin{array}{l}0.173 \\
0.408\end{array}$ & $\begin{array}{c}0.702^{* * *} \\
0.000\end{array}$ & 1.000 & \\
\hline TA & $\begin{array}{c}-0.142 \\
0.499\end{array}$ & $\begin{array}{c}-0.304 \\
0.140\end{array}$ & $\begin{array}{c}-0.333 \\
0.104\end{array}$ & $\begin{array}{l}-0.209 \\
0.317\end{array}$ & $\begin{array}{c}-0.180 \\
0.390\end{array}$ & $\begin{array}{l}0.277 \\
0.181\end{array}$ & $\begin{array}{l}0.186 \\
0.373\end{array}$ & $\begin{array}{c}-0.440^{*} \\
0.028\end{array}$ & $\begin{array}{c}-0.745^{* *} \\
0.000\end{array}$ & 1.000 \\
\hline * & At th & 11 lev & tai & the & latio & $\operatorname{sign}$ & ant. & & & \\
\hline * & & 5 lev & - & the & latic & is sig & cant. & & & \\
\hline
\end{tabular}

Source: Researchers Own Calculation from Annual Reports

In terms of $1 \%$ level of significance, it was found that there is significant correlation between current ratio and capital adequacy ratio, loan deposit ratio and earnings per share, return on assets and net profit as well as total assets and return on assets. Moreover, the significant correlation exists between earnings per share and debt-equity ratio, loan deposit ratio and debt-equity ratio, return on assets and earnings per share, market capitalization ratio and loan deposit ratio, net profit, and market capitalization as well as total assets and net profit at $5 \%$ level of significance.

\section{CONCLUSION}

To evaluate the extent of disclosure of the banking sector incorporated in Bangladesh as well as its relationship with the specific characteristics of banks are the major attempt of this study. Based on this descriptive statistics, it is found that sample bank_3 shows the highest average disclosure percentage and sample B_1 reports the lowest average disclosure percentage. However, sample bank _5 shows the lowest standard deviation, and sample bank _1 shows the highest standard deviation. In case of sample bank_1, the highest number of coefficient of variation has been observed and the lowest one is in case of sample bank _5. Along with that, the maximum percentage of disclosure has been shown in sample bank_2. Sample bank_1 shows the minimum percentage in this study. The interesting thing is the increasing and decreasing manner of disclosing information of the sample bank _2 whose percentages of disclosure score are in satisfactory level. In addition, the outcomes of ANOVA test shows that the null hypothesis is accepted. So, it is visible that the significant variation doesn't exist in the disclosure scores of information contained in annual reports of the sample banks. To identify the availability of significant 
relationship between the extent of disclosure and the specific characteristics of banks, the given study has employed the multiple regressions analysis with respective model. The results of this analysis state that the earnings per share, net profit as well as return on assets confirmed the existence of significant relationship with the extent of disclosure but capital adequacy ratio, debt-equity ratio, loan deposit ratio, current ratio, market capitalization and total assets reported the insignificant relationship with the extent of disclosure of the sample banks over the study period.

Disclosure means the effective communication with meaningful information concerned with any kinds of business oriented firms in order to deal with the different interested user's needs and maintain transparency and adequacy as well as building up the confidence of different stakeholders (Ahmed, 2021; Bynagari \& Ahmed, 2021; Neogy et al., 2014). It is important to ensure full compliance with different rules prescribed by the regulatory authorities and take necessary steps to disclose adequate information contained in the annual reports of the banking sector in Bangladesh. Based on the disclosed information, the interested stakeholders take decisions so the management should ensure the quality of information.

\section{REFERENCES}

Ahmed, A. A. A. (2021). Perception of the audience of interests on the qualitative characteristics of financial reporting. International Journal of Intellectual Property Management. https://doi.org/10.1504/IJIPM.2021.10038267

Ahmed, A. A. A., Asadullah, A. B. M. and Rahman, M. M. (2016). NGO's Financial Reporting and Human Capital Development. American Journal of Trade and Policy, 3(2), 53-60. https://doi.org/10.18034/ajtp.v3i2.401

Ahmed, A. A. A.; Paruchuri, H.; Vadlamudi, S.; \& Ganapathy, A. (2021). Cryptography in Financial Markets: Potential Channels for Future Financial Stability. Academy of Accounting and Financial Studies Journal, 25(4), 1-9. https://doi.org/10.5281/zenodo.4774829

Arif, H. M., \& Tuhin, M. H. (2013). Disclosure of non-financial information voluntarily in the annual report of financial institutions: A study on listed banks of Bangladesh. European Journal of Business and Economics, 8(2), 37-42.

Barako, D. G. (2007). Determinants of Voluntary Disclosures in Kenyan Companies Annual Reports. African Journal of Business Management, 1(5).

Bynagari, N. B. \& Ahmed, A. A. A. (2021). Anti-Money Laundering Recognition through the Gradient Boosting Classifier. Academy of Accounting and Financial Studies Journal, 25(5), 1-11. https://doi.org/10.5281/zenodo.5523918

Galani, D. (2011). The Association between the Firm Characteristics and Corporate Mandatory Disclosure, the Case of Greece. World Academy of Science, Engineering and Technology, 53.

Hasan, M. T., \& Hosain, M. Z. (2015) .Corporate Mandatory and Voluntary Disclosure Practices in Bangladesh: Evidence From Listed Companies of Dhaka Stock Exchange. Research Journal of Finance and Accounting, 6(12).

Hawashe, A. A. (2015). Commercial Banks' Attributes and Annual Voluntary Disclosure: The Case of Libya. International Journal of Accounting and Financial Reporting, 5(2). 
Hossain, M., (2008). The Extent of Disclosure in Annual Reports of Banking Companies: The Case of India. European Journal of Scientific Research, 23(4).

Hussain, S., Ahmed, A. A. A., Kurniullah, A. Z., Ramirez-Asis, E., Al-Awawdeh, N., Al-Shamayleh, N. J. M., Julca-Guerrero, F. (2021). Protection against Letters of Credit Fraud. Journal of Legal, Ethical and Regulatory Issues, 24(Special Issue 1), 1-11. https://doi.org/10.5281/zenodo.5507840

Maleque, F., Rahman, R., \& Ahmed, A. A. A. (2010). Financial Disclosure in Corporate Annual Reports: A Survey of Selected Literature. Journal of the Institute of Bangladesh Studies, Institute of Bangladesh Studies, Rajshahi University, Vol. 33.

Neogy, T. K., \& Ahmed, A. A. A. (2014). The Extent of Disclosure of Different Components of Disclosure Index: A Study on Commercial Banks in Bangladesh. Global Disclosure of Economics and Business, 4(2), 100-110.

Neogy, T. K., Amin, M. R., \& Ghosh, P. K. (2014). The Voluntary Items of Disclosure and Its Affecting Factors: A Study on Private Commercial Banks in Bangladesh. Journal of Faculty of Business Administration (JFBA), Islamic University, Kushtia, Part-C, 10(2), June.

Rahman, M. T., \& Uddin, M. M. (2016). Influence of Corporate Attributes on Magnitude of Disclosure by Private Commercial Banks in Bangladesh. Journal of Business and Technology (Dhaka), XL(1\&2), January-December.

Sharma, D. K., Chakravarthi, D. S., Shaikh, A. A., Ahmed, A. A. A., Jaiswal, S., Naved, M. (2021). The aspect of vast data management problem in healthcare sector and implementation of cloud computing technique. Materials Today: Proceedings. https://doi.org/10.1016/j.matpr.2021.07.388

Siddique, M. A. B., Islam, M. R., \& Neogy T. K. (2014). Variations in Opinions toward Disclosure Trend of Insurance Companies in Bangladesh: An Empirical Study. American Journal of Trade and Policy, 1(1).

Zhu, Y., Kamal, E. M., Gao, G., Ahmed, A. A. A., Asadullah, A., Donepudi, P. K. (2021). Excellence of Financial Reporting Information and Investment Productivity. International Journal of Nonlinear Analysis and Applications, 12(1), 75-86. https://doi.org/10.22075/ijnaa.2021.4659 
Article URL

https://i-proclaim.my/journals/index.php/abcjar/article/view/571 